\title{
THE SOCIAL, EMOTIONAL AND SEXUAL IMPLICATIONS EXPERIENCED BY OSTOMIZED WOMEN ATTENDING IN PRIMARY HEALTH CARE
}

\author{
IMPLICAÇÕES SOCIAIS, EMOCIONAIS E SEXUAIS VIVENCIADAS POR \\ MULHERES OSTOMIZADAS ATENDIDAS NA ATENÇÃO PRIMÁRIA A SAÚDE
}

\author{
Larisse Faustino da SILVA ${ }^{1}$; Bruno Bordin PELAZZA²; Luiz Almeida da SILVA²; \\ Ludmila Grego MAIA ${ }^{2}$; Giulena Rosa LEITE $^{2}$; Cácia Régia de PAULA ${ }^{2}$; \\ Marlene Martins ANDRADE ${ }^{2}$; Maria Regiane TRINCAUS ${ }^{3}$; Guilherme Silva MENDONÇA ${ }^{4}$; \\ Renata Alessandra EVANGELISTA ${ }^{5}$; Alexandre de Assis BUENO ${ }^{6}$ \\ 1. Academic of Nursing, Federal University of Goiás, Jataí, GO, Brazil; 2 - Professor at the Federal University of Goiás, Jataí, GO, \\ Brazil. bordizim@ @otmail.com; 3. Professor Assistant level C of the State University of the Western Center, Brazil; 4. Nurse, \\ Pedagogue, Master in Health Sciences, Federal University of Uberlândia, Uberlândia, MG, Brazil; 5. Professor at the Federal University \\ of Goiás, Catalão, GO, Brazil.
}

\begin{abstract}
To gain knowledge into the social, emotional and sexual implications experienced by women attending the Ostomy Program in the municipality of Jataí-GO. This is a descriptive, exploratory and qualitative approach. The research was conducted in a basic care service, between May and September 2016. Eleven women were interviewed, using a semi-structured questionnaire and an audio recorder. The implications lived by these women in the social, emotional and sexual domains were evident. Through the accounts provided, it was possible to perceive sadness, fear and nonconformity in coming to terms with their new reality. The suffering reported by some patients was visible and from such, they need arose for the creation and implantation of a support group, in which it was possible for these women to exchange experiences.
\end{abstract}

PALAVRAS-CHAVE: Ostomy. Women. Stress. Psychological. Surgical Stomas. Sexuality.

\section{INTRODUCTION}

The word ostomy has its origins in Greek and takes the meaning of mouth or artificial opening of a hollow organ, which aims at its exteriorization at the surface of the body (GEMELLI; ZAGO, 2002). This surgical procedure can take different denominations, depending on the exteriorized organ or segment, or be it, in the small intestine it is classified as ileostomy, in the large intestine, colostomy, and bladder, urostomy. In addition, this can also be classified by the length of stay, form of externalization, continence, maturation and access route (ALVES et al., 2013; NASCIMENTO et al., 2011; MINISTÉRIO DA SAÚDE, 2009).

According to the study performed by Maurício, Souza and Lisboa (2013), the existence of intestinal or urinary ostomy modifies the lives of the patients, due to the loss of sphincter control and the presence of the collector bag. This modification obliges the patient to adapt to their new requirements. Thus to live with this physical alteration becomes extremely complex, which generates doubts, fear and inhibition. In this sense, patients that have been ostomized pass through significant changes, which bring about alterations to their social, emotional and sexual lives (CETOLIN et al, 2013).
Those women that have been ostomized present altered social habits, such as not going to the workplace, social isolation, deprivation of leisure moments and separation from the family. In this manner, their removal from places of routine becomes more frequent, beside there being the reality of the constant worry with ostomy bag breaches in public places (NASCIMENTO et al., 2011).

In the field of emotions, the main concern is the alteration of the esthetic image of the body, as this produces the thought of being mutilated, which generates a sentiment of rejection when dealing with their body (GEMELLI, ZAGO, 2002; SALES et al., 2010). Therefore, it is common to see the development of a mixture of sentiments, such as fear of the unknown, denial of the new reality and questioning of the type; how and why has this happened to me? In some cases, the patients develop low self-esteem and depression when facing up to these new implications (ALVES et al., 2013).

In this context, some changes can be seen, among such are those associated with sexual intercourse in these women. These are related to the rejection by their partner, through insecurity due to the alterations related to their body. In addition, there is a tendency toward decreased libido, 
dyspareunia and the fear of returning to sexual intercourse (SANTOS et al., 2013).

The role played by the nursing team in light of the complications experienced by these women is of extreme relevance. This professional should be prepared to attend to the social emotional and sexual alterations presented by the patient. The support care for this specific group of patients is a challenge, where health education, directives and clarification of possible doubts play an essential role (ALVES et al., 2013; NASCIMENTO et al., 2011; MAURICIO e. al., 2013; CETOLIN et al., 2013; SALES et al., 2010; SANTOS et al., 2013).

From the readings made and the contact with the Ostomy Program in the Municipality of the performed study, there arose the need to research this group of patients and their peculiarities. Through this contact, the following guiding question arose; what are the implications experienced by these ostomized women in the social, emotional and sexual fields? In this sense, this study took on the objective of understanding the social, emotional and sexual implications experienced by these ostomized women.

\section{METHOD}

The method herein is based on a descriptive, exploratory and qualitative approach study. The research was carried out in a basic health care service at a municipality from southeast Goiania, where the Ostomy Program (OP) has been implemented since 2011. The SHU is responsible for attending to ostomized patients of regional health service Southeast II, from the state of Goiás. In addition to the mentioned municipality, there are another nine municipalities of regional health service under the jurisdiction of the above mentioned regional health service.

The selection criteria were feminine, older than 18 years of age, registered on the OP, they should maintain regular follow-ups with the multidisciplinary team, possess a temporary or permanent ostomy. There exist a total of 12 patients registered on the OP, where 11 fulfilled the selection criteria and accepted to participate in the study, or be it, one patient was excluded from the study.

The data collection occurred between the months of May to September of 2016. A semistructured interview script was used, with closed questions for the sociodemographic characterization of the participants and open questions for identifying the perception of the implications experienced by these individuals. The interviews were performed in the SHU and in some cases at the residence of the patients. Noteworthy here is that the interviews were performed in a quiet and reserved location. In this manner, there was concern as to minimizing any embarrassment or unease in answering the questionnaires.

Subsequently, the audio accounts were transcribed in full. With the interviews at hand, these were read successively until it was possible to code the speeches of the patients, in questions related to changes that occur in the social, emotional and sexual fields.

The collected data was analyzed in accordance with the content analysis of Bardin (2011). The anonymity of the participants was preserved, with identification being made through the letter M, all identified by the initial letter of the word "Mulher" (woman), and followed by the numbers related to quantity of patients in the study: M1 to M11.

This study is in accordance with resolution $n^{\circ} 466 / 12$ and was approved by the Ethics Committee for Research at the Federal University of Goiás, under the number 1.008 .808 , on the 27 th of September 2016.

\section{RESULTS AND DISCUSSION}

\section{Characterization of the population}

This study was performed with 11 ostomized women, with an average age of 59 years. In this manner, the sociodemographic data are demonstrated on Table I and the reference data to ostomy characterization on Table II.

Note on Table I that $55 \%$ of the patients declare themselves as brown skinned. There was a predominance of single women and women living in cohabitation (each responsible for $27.3 \%$ ), followed by married and divorced (each responsible for $18.2 \%$ ), and one widowed. In regards to the education of the patients, $36.4 \%$ reported to have completed fundamental education, while $27.3 \%$ had completed high school and/or higher and only two patients had not completed fundamental education or high school.

Regarding profession, a majority had no employment link, with a preference to developing activities within the home, which represented $54.5 \%$. Noted here was that a majority of the families were of low income, which varied between 1 and 3 minimum salaries $(73 \%)$. Two patients received incomes of between 3 and 5 minimum salaries (18.2\%), and one refrained from answering.

In relation to Family composition, the study revealed that the patients reside with more than one 
person, among which are companion, children and grandchildren. In terms of religion, $45.4 \%$ of those interviewed reported to be catholic, $36.4 \%$ confessed to be evangelical and $18.2 \%$ said that they had no religion, which does not mean there is no belief in a superior being.

Table 1. Sociodemographic data, Ostomy Program from a municipality from southeast Goias, 2016.

\begin{tabular}{|c|c|c|c|c|c|c|c|}
\hline Patient & Race & $\begin{array}{r}\text { Marital } \\
\text { status }\end{array}$ & Profession & Education & $\begin{array}{l}\text { Income } \\
\text { in } \\
\text { Salaries }\end{array}$ & $\begin{array}{c}\text { Family } \\
\text { composition }\end{array}$ & Religion \\
\hline M1 & Brown & $\begin{array}{c}\text { Cohabitatio } \\
n\end{array}$ & From home & $\begin{array}{l}\text { High school } \\
\text { Incomplete }\end{array}$ & 1 to 3 & 4 & $\begin{array}{l}\text { No preference } \\
\text { given }\end{array}$ \\
\hline M2 & Brown & Single & From home & $\begin{array}{l}\text { Fundamenta } \\
\text { 1 Complete }\end{array}$ & 3 to 5 & 5 & Evangelist \\
\hline M3 & Brown & Divorced & Dress maker & $\begin{array}{l}\text { Fundamenta } \\
1 \text { Complete }\end{array}$ & 1 to 3 & $\begin{array}{l}\text { Only the } \\
\text { patient }\end{array}$ & Evangelist \\
\hline M4 & White & Widow & From home & $\begin{array}{l}\text { Fundamenta } \\
1 \text { Complete }\end{array}$ & 1 to 3 & 2 & Catholic \\
\hline M5 & Brown & Married & From home & $\begin{array}{l}\text { High school } \\
\text { Complete }\end{array}$ & 1 to 3 & 6 & Catholic \\
\hline M6 & White & Single & Teacher & $\begin{array}{l}\text { Further } \\
\text { education }\end{array}$ & 3 to 5 & 5 & $\begin{array}{l}\text { No preference } \\
\text { given }\end{array}$ \\
\hline M7 & White & Divorced & Teacher & $\begin{array}{l}\text { Complete } \\
\text { Further } \\
\text { education } \\
\text { Complete }\end{array}$ & 1 to 3 & 3 & Catholic \\
\hline M8 & White & $\begin{array}{c}\text { Cohabitatio } \\
n\end{array}$ & From home & $\begin{array}{l}\text { High school } \\
\text { Complete }\end{array}$ & 1 to 3 & 3 & $\begin{array}{l}\text { No preference } \\
\text { given }\end{array}$ \\
\hline M9 & Brown & Single & Receptionist & $\begin{array}{l}\text { Further } \\
\text { education } \\
\text { Complete }\end{array}$ & 1 to 3 & 4 & $\begin{array}{l}\text { No preference } \\
\text { given }\end{array}$ \\
\hline M10 & White & $\begin{array}{c}\text { Cohabitatio } \\
n\end{array}$ & From home & $\begin{array}{c}\text { Fundamenta } \\
1 \\
\text { Incomplete }\end{array}$ & 1 to 3 & 4 & Catholic \\
\hline M11 & Brown & Married & From lar & $\begin{array}{l}\text { High school } \\
\text { Complete }\end{array}$ & $\begin{array}{l}\text { Declined } \\
\text { to answer }\end{array}$ & 3 & Catholic \\
\hline
\end{tabular}

Table II shows that the most predominant type of surgery was the colostomy $(54.5 \%)$, followed by ileostomy (27.3\%) and then urostomy and a singular patient did not know which surgery was performed. Regarding the type of ostomy, $54.5 \%$ reported to have a permanent ostomy and $45.5 \%$, a temporary ostomy.

In terms of medical condition of the patient, which resulted in the performed surgery, 27.3\% reported to have developed cancer of the intestine and the anus. In addition, there were reported cases of cancer of the bladder and uterus. Each condition presented a $9.1 \%$ percentage rate. One patient was reported to have developed Crohn disease and another did not know what caused the need for her surgery, each individual was represented. These data are in agreement with the Literature that refers to the main causes leading to the creation or construction of stomas in individuals, when related to traumas, inflammatory disease and mainly cancer (GEMELLI, ZAGO, 2002)

Table 2. Ostomy data, Ostomy Program from the city of Jataí-GO, 2016.

\begin{tabular}{cccc}
\hline Patient & Type of surgery & Type of Ostomy & Disease \\
\hline M1 & Colostomy & Temporary & Crohn Disease \\
M2 & Ileostomy & Temporary & Colorectal tumor \\
M3 & Ileostomy & Definitive & Cancer of the rectum
\end{tabular}




\begin{tabular}{cccc} 
M4 & Urostomy & Definitive & Cancer of the bladder \\
M5 & Colostomy & Definitive & Cancer of the rectum \\
M6 & Colostomy & Definitive & Cancer of the uterus \\
M7 & Ileostomy & Temporary & No definitive diagnosis \\
M8 & Colostomy & Definitive & Cancer of the rectum \\
M9 & Does not know & Temporary & Cancer of the intestine \\
M10 & Colostomy & Temporary & Cancer of the intestine \\
M11 & Colostomy & Definitive & Cancer of the intestine \\
\hline
\end{tabular}

\section{Social implications reported by ostomized women}

In this category, questions were put forward with the aim of understanding the social changes that ostomized women go on to experience. When questioned if there had been changes to their social environment, we received the following answers.

I noted that the bag was giving a problem, and this happens, it is not because we want it, when you look down it is already happening. (M2)

I first went to dances, now I don't go anymore...Today I rarely go to see my relatives, I'm not even going to my daughter's house anymore. (M3)

A lot! I nearly don't go out, because I ended up with a sequela, that's right, from the surgery and now I' $m$ using a cloth the whole time. It was leaking under the collector bag. Today, I only go to church...Because I am scared of an embarrassing situation near others, at first the bag would not stick at all. It became unstuck, it got me completely dirty, the bag was a serious problem. (M4)

I did! I did not go to many parties in other houses, I don't go to family parties, I go more to spaces where there are toilets that I can use easily, but these are few. (M6)

According to Nascimento (2011), many patients report significant changes to their social environment, due to the difficulties related to leisure, work, carrying out daily activities and restriction in social settings.

The physiological changes are the ones that most interfere in social relationships of these individuals, mainly those related to the elimination of faeces, to the odour and the obligatory use of a device attached to the abdomen (GEMELLI, ZAGO, 2002) These on many occasions are the cause of insecurity due to bad fixing or bad quality of the device used as reported in the study by Coelho, Santos and Poggeto (2013). In these cases, there is evidence that the lack of leisure activities is related to insecurity over the collector bag, the lack of structure in public places and the possible sequelae due to surgery. These situations were verified through the testimonials given by M2, M4 and M6.

In the study by Torres et al. (2015), which worked with the life quality of ostomized individuals, they noted that the creation of an ostomy in any patient, entails relevant impacts on the social life of this population, these are in principal related to the lack of control in the production and elimination of faeces in public places.

In this study, one notes reports of women that stopped going to public places, are absent from or decrease visits to homes of loved ones, as they feel unprepared to deal with emergencies, which may become the cause for embarrassment in the family or social environment.

I only go to some places, like that...Only when it is more on the side of the family. In other places I don't have the habit of going, I'm scared. (M1)

I go, to a relative, I don't like to stay over, I like to go and come back...In the past I stayed over at my relatives house, not now. And how! I had a problem with the bag, it wouldn't stick. So, I had that worry of going out the house and the bag breaking and leaking everywhere. (M2)

... I nearly never leave the house. I only go to pay bills. I rarely go to a neighbor's house like this.. (M3)

The impacts caused by the ostomy on the carrying out of daily activities and the limitations related to the work environment were also questioned. It was noted that, through these reports, some individuals stopped doing or decreased their participation in daily activities. Simple activities went on to be unadvisable, such as house cleaning, dressmaking, and any heavy lifting. In addition, in their speech we noted difficulties and the fear of going back to work. 
I do all of this, but I can't lift any weight. For you to have an idea, I can't even lift up my daughter. (M1)

I do basically everything, only with difficulty. For example, the day I do my dressmaking, the bag hurts me a lot. Also, I can't remain sat down for very long and not even clean. (M4)

After I had surgery, I didn't go back to work. Today, I only wash the bowls and make food, the rest I can't do. (M8)

I am on work leave, because of the ostomy and all my activities have changed. I can imagine that it must be very difficult to go back to work, and soon I will have to. And when the bag fills or breaks, what am I going to do?...In the middle of a classroom or in a course in which you are giving class? (M11)

The results from this study are in line with that of Coelho, Santos and Poggeto (2013), which showed the limitations or the loss in relation to work capacity. Noteworthy here is that the anatomical changes and the lack of control over the volume stored in the collector bag contribute to the rapid perception of the limitations, which consequently lead to modifications in daily routine activities.

\section{Emotional implications reported by ostomized women}

In this category, there was questioning related to the feelings developed by women with an ostomy. Inquiries were made as to whether they had support from family members and/or other people with any special significance to their lives during the diagnoses process, surgery and adaptation.

Some women reported to have had support, where it was possible to note through what was said by the patients, the degree of importance given to family support, how it was decisive in facing the processes, all this can be noted from the following statements.

I had! I had yes, my husband was always there by my side... [Choro]. (M1)

I had! I have my sister that gave up nearly everything to stay with me during the treatment...She accompanied me and still does until today. (M4)

And how I had! So many friends, the group from the gym, the people from the gym gave me a lot of support, many came to visit, even the SAMU chief from here in Jataí that today lives in Goiânia also visited me... (M5)

I had! Thank God, I had. (M9)

The study by Barbosa et al (2014) highlights that the family support is necessary, due to the security that it represents in terms of acceptance and insertion of the ostomized individuals in society..

On the other hand, when a lack of family support was observed, feelings of sadness, abandonment and in some cases revolt are seen among these women. As the family environment is the place, in which one hopes to find support, comfort and protection. In this sense, the words below express sentiments of abandonment, caused by the lack of support. The findings here are different from those found in the study of Pereira et. al. (2015), which demonstrated that all its participants reported to have had support from family, friends, professionals and other people that had a significant affectionate meaning personal to each.

A little! They are always working, without any time, however, they helped a little...they could have helped a little more. (M3)

No! No, I lived alone! Well, I and my companion in Vitória-ES. There were none of my sisters or children. They could have gone! So, I really missed the love from loved ones. (M6)

The difficulties found by ostomized patients, according to Nascimento et al. (2011), can be of emotional origin. In this manner, the patients can develop feelings of shame toward their partner, family and friends. The same Literature also covers the sensation described by these individuals, of feeling dirty and of presenting a repugnant appearance. This corroborates the findings of this study, through questioning patients as to which sentiments they had developed after the ostomy, the following answers were given.

I did not feel Shame, I felt Disgust!...and you have to get used to it! You try to get used to it, but you never do. [Crying]... It's difficult. (M1)

SADNESS AND DEPRESSION! Disgust! Shame, no. So, sadness at the moment you realize that you will need to use a bag. (M6)

When I passed my hand over my belly and felt that bag, I asked myself what is this? It was a big surprise and disgust. There are so many emotions that you don't know how to distinguish them, there is surprise, disgust, insecurity. It is a mixture of feelings! (M11)

According to Pereira et al. (2015), the altered esthetic image of the body is the aspect of greatest emotional and psychological impact in an ostomized patient. According to this researcher, the esthetic image of the body is related to the way we think and feel about our body. In this respect, for Alves et al. (2013), the emotional aspect is the one that brings most concern, where the alteration of the physical image is a factor to be worked on, as the 
sensation of mutilation developed by the patients entails various sentiments, among which is disgust, where a feeling of rejection toward their own body is evident.

The findings from this study corroborate those from the above Literature, as upon analyzing the responses from the interviews, one notes that alterations to the body, which result from surgical procedure and the use of the collector device, produce a defense mechanism effect. This effect is manifest in the patients through their simple refusal to look in the mirror, use of baggy clothes, besides describing their body as something intolerable. Upon being questioned about the changes that occur after surgery and what was the vision they had of their body, there was noted the development of the feelings of disgust, displeasure and nonconformity. Thus, they describe what they feel in relation to their body, as in the following opinions.

Ah! I'm finished (laughs). I'm all messed up and the clothes that I used before, I don't use anymore! In the past, I only used tight-fitting clothes. My belly is all cut up, it's finished. (M1)

Look, a big change! Because of the ostomy, the bag is stuck here just hanging. You look in the mirror and say to yourself: I was this and now I am this! (M6)

Deformed! I look at my body as something deformed. I think it is strange. I don't look in the mirror, I don't have the courage, I find the whole thing very strange. (M11)

It is understood that the coming to terms with this new corporal image, "mutilated" "deformed" requires the wholehearted support of the family, in order that this woman can accept this new episode in her life and return to have an active social life. We understand that the role of the nursing team is of vital importance during these two phases. The indication of the correct devices, the education of both patients and family in the use and placement of these devices correctly, can make the difference between an active or redundant social life, between acceptance of themselves and disgust toward their body (GEMELLI; ZAGO, 2002). The essence of nursing, which is to care for the other, becomes apparent in this situation, in those moments when direct care is necessary along with the moment that she needs education and learning to following on with the self-care in her new life, in the light of this ostomy. For the researchers Gemelli and Zago (2002), the directives given for care arise from a strategy that aims at the valorization of special care, as well as the recognition of the individual with the ostomy as a special individual.

\section{Sexual implications related to ostomized women}

Living with a device such as an ostomeric bag can generate conflicting sentiments, concerns and difficulties in dealing with this new situation (CARDOSO et al., 20015), among such situations, one finds the difficulty in returning to an active sexual life for some women.

In this research, only two women report to having had returned to sexual practices, although with some limitations. One reported that the greatest change in her sex life was the limitation to the sexual positions and the other described the lack of lubrication, and the decrease in libido upon returning to such practices.

Concerning the question of position. Today he has to be more careful with me, slower, there are certain positions that we don't do. (M1)

I had! Practically my libido has gone and this was something that I didn't want at that moment. I was afraid, as when I cleaned my anus and the tumor in the uterus also affected my vagina. I very nearly lost my vagina as well. IAs a result, my vagina became dry, and very closed, so, I lost my desire. (M6)

According to the study by Santos et al. (2013), colostomized women report difficulties in returning to sexual activity, for motives of shame as well as the complications developed after surgery. In this manner, the sexual act goes on to have a secondary importance.

In a study conducted by Torres et al. (2015), participates report not returning to sexual practices. The data corroborate with the findings found in the Literature. According to Silva et al. (2016), the questions put forward in relation to sexuality are of a difficult nature to evaluate, as they deal with a subjective theme of female intimacy, and many times there are restrictions in the reports linked to the modifications that result from an ostomy. It was noted that anatomic alterations profoundly modify the sexual life of ostomized individuals.

When questioned if they had felt at a loss after the surgery in returning to sexual practices, patient M6 reported that the greatest loss was the decrease in sexual routine. In this manner, today sexual activity only happens when they feel prepared, which can be noted in their speech.

The losses felt were the decrease of sexual routine. Today, this happens when I want it, because my libido decreased a lot. So, my partner waits, it happens if I want it to. (M6)

The patient M1, report demonstrated the importance of understanding and support from her companion. Even with the modifications that result from the ostomy, and the changes to sex life, she did 
not classify these alterations and changes as a loss, as when questioned about losses developed after surgery, she reported:

I didn't have any! The fact is my husband is very understanding, you know he loves me a lot, this helps me very much, he cares for me. (M1)

Companion support is fundamental for the return to sexual practices. Through incentivizing her and participating in the processes related to surgery, he goes on to become an important piece in the rehabilitation of his companion, by showing his wife that she is being supported. In feeling supported, loved and protected, the patient will bring to her partner her fears, anxiety and difficulties, a type of understanding that favors the return to sexual practices (SANTOS et al., 2013).

\section{CONCLUSION}

This study shed light on some of the implications lived by ostomized women in their social, emotional and sexual lives, which provided a better understanding into their needs that were shown to go far beyond the studied themes. After making contact with the women attended at the OP, it was noted that each woman had her own particular and unique manner of dealing with the whole process of illness, with the aim of simplifying their daily lives and to facilitate their new reality. In the light of such events, it was possible to see the magnitude of the impact an ostomy has on the lives of these women. The fear felt when faced with this new reality, the social isolation, the shame of passing through an embarrassing situation in public, the feeling of abandonment by family members, friends and their partners, besides having to live with an altered corporal image. After contact with the women from the OP, the need was awoken for the implementation of a support group in the health units where care is provided to this population. The result is to create an environment where they can exchange experiences and information on their new reality and the way that each developed to overcome the difficulties they experienced.

Although this is a subject with a degree of national production and peculiarities, it was noted that still there exists a large gap in the application of these studies in the practical profession. We thus highlight that this is a first study from the southeast of Goiania, which has shown the social emotional and sexual implications experienced by ostomized women.

RESUMO: Conhecer as implicações sociais, emocionais e sexuais vivenciadas por mulheres atendidas no Programa de Ostomia no município de Jataí-GO. Trata-se de um estudo descritivo, de abordagem qualitativa, realizado na atenção básica entre os meses de maio a setembro de 2016. Foram entrevistadas 11 mulheres, com auxílio de um questionário semiestruturado com perguntas pertinentes ao tema. Ficaram evidentes as implicações vivenciadas por essas mulheres, nos campos social, emocional e sexual. Nos relatos foi possível perceber tristeza, medo e inconformismo frente a sua nova realidade. Constatou-se o sofrimento relatado por algumas pacientes, e desses relatos surgiu a necessidade da criação e implantação de um grupo de apoio no qual fosse possível a troca de experiências e vivências dessas mulheres.

PALAVRAS-CHAVE: Estomia. Mulheres. Estresse psicológico. Estomas cirúrgicos. Sexualidade.

\section{REFERÊNCIAS}

ALVES, R. C. P.; MOREIRA, K. C. R.; FRANCO, C. P. P.; OLIVEIRA, D. C. A percepção do paciente portador de ostomia com relação a sua sexualidade. Revista Interdisciplinar, Teresina, v. 6, n. 3, p. 26-35, 2013. ISSN 2317-5079

BARBOSA, M. A.; POGGETTO, M. T. D.; BARICHELlO, E.; DE CUNHA, D. F.; DA SILVA, R.; ALVES, P. I. C.; LUIZ, R. B. Aspectos clínicos e epidemiológicos de estomizados intestinais de um município de Minas Gerais. Revista de Enfermagem e Atenção à Saúde, Uberaba, v. 3, n. 1, p.64-73, 2014.

BARDIN, L. Análise de conteúdo. São Paulo: Edições 70, 2011.

BARROS, E. J. L.; SANTOS, S. S. C.; GOMES, G. C.; ERDMANN, A. L. Gerontotecnologia educativa voltada ao idoso estomizado à luz da Complexidade. Revista Gaúcha de Enfermagem, Porto Alegre, v. 33, n. 2, p. 95-101, 2012. https://doi.org/10.1590/S1983-14472012000200014 
CARDOSO, D. B. R.; ALMEIDA, C. E.; DE SANTANA, M. E.; DE CARVALHO, D. S.; SONOBE, H. M.; SAWADA, N. O. Sexualidade de pessoas com estomias intestinais. Revista da Rede de Enfermagem do Nordeste, Fortaleza, v. 16, n. 4, p. 576-585, jul-ago, 2015. https://doi.org/10.15253/2175-6783.2015000400015

CARDOSO, D. B. R.; ALMEIDA, C. E.; SANTANA, M. E.; CARVALHO, D. S.; SOBONE, H. M.; SAWADA, N. O. Sexualidade de pessoas com estomias intestinais. Revista da Rede de Enfermagem do Nordeste, Fortaleza, v. 16, n. 4, p. 576-85, 2015.

CETOLIN, S. F.; BELTRAME, V.; CETOLIN, S. K.; PRESTA, A. A. Dinâmica sócio-familiar com pacientes portadores de ostomia intestinal definitiva. Arquivos Brasileiros de Cirurgia Digestiva, Curitiba, v. 26, n. 3, p. 170-72, 2013. https://doi.org/10.1590/S0102-67202013000300003

COELHO, A. R.; SANTOS, F. S.; POGGETTO, M. T. D. A estomia mudando a vida: enfrentar para viver. Revista Mineira de Enfermagem, Belo Horizonte, v. 17, n. 2, p. 258-267, 2013.

GEMELLI, L. M. G.; ZAGO, M. M. F. A interpretação do cuidado com o ostomizado na visão do enfermeiro: um estudo de caso. Revista. Latino-Americana de Enfermagem, Ribeirão Preto, v. 10, n. 1, p. 34-40, Jan. 2002. https://doi.org/10.1590/S0104-11692002000100006

MAURICIO, V. C.; SOUZA, N. V. D. O.; LISBOA, M. T. L. O enfermeiro e sua participação no processo de reabilitação da pessoa com estoma. Escola Anna Nery, Rio de Janeiro, v. 17, n. 3, p. 416-422, 2013. http://dx.doi.org/10.1590/S1414-81452013000300003

MINISTÉRIO DA SAÚDE. Portaria no 400, de 16 de novembro de 2009. Brasília, 2009. Acessado em: 09 de julgo de 2017. http://bvsms.saude.gov.br/bvs/saudelegis/sas/2009/prt0400_16_11_2009.html

NASCIMENTO, C. M. S.; TRINDADE, G. L. B.; LUZ, M. H. B. A.; SANTIAGO, R. F. Vivência do paciente estomizado: uma contribuição para a assistência de enfermagem. Texto Contexto Enfermagem, Florianópolis, v. 20, n. 3, p. 557-64, 2011. https://doi.org/10.1590/S0104-07072011000300018

PEREIRA, A. P. S.; CARNEIRO, C. C.; PINTO, M. H.; MARTINS, M. R. I.; NETINHO, J. G.; CESARINO, C. B. Percepções dos estomizados intestinais sobre o estoma após cirurgia. Ciência Cuidado e Saúde, Maringá, v. 14, n. 2, p. 1051-1057, 2015. https://doi.org/10.4025/cienccuidsaude.v14i2.21692

SALES, C. A.; VIOLIN, M. R.; WAIDMAN, M. A. P.; MARCON, S. S.; SILVA, M. A. P. Sentimentos de pessoas ostomizadas: compreensão existencial. Revista da Escola de Enfermagem da USP, São Paulo, v. 44, n. 1, p. 221-7, 2010. https://doi.org/10.1590/S0080-62342010000100031

SANTOS, S. R.; MEDEIROS, A. L.; CABRAL, R. W. L.; ANSELMO, M. N. S.; SOUZA, M. C. J. Sexualidade de portadoras de estoma intestinal definitivo: percepção de mulheres. Enfermagem em Foco, Brasília, v. 4, n. 2, p. 119-22, 2013.

SILVA, A. L.; KAMADA, I.; SOUSA, J. B.; VIANNA, A. L.; OLIVEIRA, P. G. Singularidades da convivência do cônjuge e seu parceiro estomizado. Revista ESTIMA, São Paulo, v. 14, n. 2, p. 68-75, 2016. https://doi.org/10.5327/Z1806-3144201600020004

TORRES, C. R. D.; ANDRADE, E. M. L. R.; RIBEIRO, F. M. S. S. R.; NETA, F. C. C. G.; LUZ, M. H. B. A. Qualidade de vida de pessoas estomizadas: revisão integrativa. Revista de Enfermagem da UFPI, Piauí, v. 4, n. 1, p. 117-22, 2015. 